\title{
KONDISI KUALITAS PERAIRAN DI KABUPATEN MOROWALI PROVINSI SULAWESI TENGAH: PENDEKATAN SPASIAL DAN STATISTIK MULTIVARIAT
}

\author{
I Nyoman Radiarta"), Hasnawi" ${ }^{* *}$, dan Akhmad Mustafa"*) \\ *) Pusat Penelitian dan Pengembangan Perikanan Budidaya \\ Jl. Ragunan 20, Pasar Minggu, Jakarta Selatan 12540 \\ E-mail: radiarta@yahoo.com \\ *) Balai Penelitian dan Pengembangan Budidaya Air Payau \\ Jl. Makmur Dg. Sitakka No. 129, Maros 90512, Sulawesi Selatan
}

(Naskah diterima: 22 Februari 2012; Disetujui publikasi: 27 Mei 2013)

\begin{abstract}
ABSTRAK
Kondisi kualitas perairan di suatu wilayah dapat dipengaruhi oleh berbagai faktor, di antaranya proses alami dan dampak dari aktivitas manusia. Oleh karena itu, pemantauan kualitas perairan yang dapat memberikan estimasi kualitas perairan yang representatif dan sesuai sangat diperlukan. Statistik multivariat yang dikombinasikan dengan analisis spasial telah digunakan dalam penelitian ini untuk menganalisis kondisi kualitas perairan di Kabupaten Morowali. Sembilan parameter penting kualitas perairan telah dikumpulkan pada bulan Juni 2011 . Hasil analisis klaster menunjukkan bahwa kualitas perairan di lokasi penelitian dikategorikan menjadi dua kelompok (klaster 1 dan 2). Dengan menggunakan analisis komponen utama diperoleh sebanyak empat signifikan komponen dengan persentase kumulatif sebesar $69,180 \%$ dari total ragam. Analisis spasial dari komponen utama menunjukkan pola yang serupa dengan klaster analisis yaitu secara umum wilayah penelitian terbagi menjadi dua wilayah dengan karakteristik yang berbeda. Dengan pendekatan statistik multivariat ini dapat digunakan untuk merancang pengambilan titik pengamatan di masa yang akan datang sehingga lebih efektif dan efisien.
\end{abstract}

KATA KUNCl: kualitas air, analisis komponen utama, analisis klaster, analisis spasial, Morowali

ABSTRACT: Water quality condition in Morowali District Central Sulawesi Province: spatial and multivariate statistical approach. By: I Nyoman Radiarta, Hasnawi, and Akhmad Mustafa

Surface waters quality in a region is largely determined by both natural processes and anthropogenic inputs. Therefore, a monitoring program providing a representative and reliable estimation of the quality of surface waters, is necessary. Multivariate statistical technique combined with spatial analysis was applied in this study in order to analyze water quality condition in Morowali District. Nine important water quality parameters were collected in June 2011. Cluster analysis results showed that water quality in the study area is classified into two groups (cluster 1 and 2). Using principal component analysis, four components were identified as being responsible for the data structure explaining $69.180 \%$ of the total variance of the dataset. Spatial analysis from the principal component indicated similar pattern with cluster analysis, which categorized the study area into two areas with different 
characteristics. Based on obtained information, it is possible to design an optimal sampling strategy that can reduce the number of sampling sites and associated cost.

\section{KEYWORDS: water quality, principal component analysis, cluster analysis, spatial analysis, Morowali}

\section{PENDAHULUAN}

Kondisi kualitas perairan di suatu wilayah dapat dipengaruhi oleh berbagai faktor, di antaranya proses alami (cuaca dan sedimentasi) dan dampak dari aktivitas manusia (anthropogenic). Karena adanya perbedaan baik waktu (temporal) maupun ruang (spatial) dari karakteristik kualitas perairan, program pemantauan secara berkala yang dapat menghasilkan estimasi kondisi kualitas perairan secara representatif dan komprehensif sangat diperlukan. Tujuan utama pemantauan kualitas perairan adalah untuk mengontrol dan meminimalkan dampak yang ditimbulkan dari pencemaran ke dalam perairan sehingga dapat menghasilkan air dengan kualitas standar bagi penggunanya, seperti misalnya air minum, irigasi, perikanan budidaya, dan pariwisata (Boyacioglu, 2006). Sehubungan dengan standar kualitas air, Kementerian Negara Lingkungan Hidup telah menetapkan Keputusan Menteri Negara Lingkungan Hidup Nomor 51 tahun 2004 tentang baku mutu air laut (KLH, 2004). Dasar pertimbangan keputusan ini adalah untuk menjaga kelestarian fungsi lingkungan laut sehingga perlu dilakukan upaya pengendalian terhadap kegiatankegiatan yang dapat mencemari dan atau merusak lingkungan laut.

Kabupaten Morowali terletak pada posisi $121^{\circ} 02^{\prime} 24^{\prime \prime}-123^{\circ} 15^{\prime} 36^{\prime \prime}$ Bujur Timur dan $01^{\circ} 31^{\prime} 12^{\prime \prime}-03^{\circ} 46^{\prime} 48^{\prime \prime}$ Lintang Selatan. Kabupaten ini memiliki luasan sekitar 45.453 $\mathrm{km}^{2}$ yang terdiri atas wilayah daratan seluas $15.490 \mathrm{~km}^{2}$ dan perairan seluas $29.963 \mathrm{~km}^{2}$ (Anonim, 2011). Karakteristik wilayah Kabupaten Morowali umumnya merupakan kabupaten pantai dengan panjang garis pantai sekitar $650 \mathrm{~km}$, kecamatan yang terdapat di kabupaten ini sebagian besar merupakan kecamatan pesisir, yang memiliki banyak pulau-pulau kecil. Luasnya perairan pesisir yang dimiliki kabupaten ini, merupakan sumberdaya lahan yang dapat dimanfaatkan untuk budidaya rumput laut. Sehubungan dengan potensi yang dimiliki, Kabupaten Morowali telah ditetapkan sebagai wilayah percontohan kawasan minapolitan melalui Keputusan Dirjen Perikanan Budidaya No. KEP.70/DJ-PB/2010. Secara konstitusional, pemerintah daerah melalui Keputusan Bupati Morowali No. 523-3/SK.017/DKPD/IX/2010 juga telah menetapkan kawasan inti (sentra) pengembangan minapolitan yaitu di Desa Laroenai Kecamatan Bungku Selatan dan daerah penyangga (hinterland) desa lainnya di Kecamatan Bungku Selatan dengan komoditas pengembangan adalah rumput laut (Kappaphycus alvarezii). Aktivitas budidaya rumput laut di kabupaten ini dilakukan dengan metode apung (long line). Untuk mendukung aktivitas budidaya rumput laut tersebut, pemantauan kondisi kualitas perairan sangat diperlukan.

Data yang dikumpulkan dalam rangka pemantauan kondisi kualitas perairan umumnya terdiri atas parameter fisik, kimia, dan biologi. Data tersebut dapat mengandung informasi yang kaya tentang kondisi/karakteristik sumberdaya perairan. Seringkali dalam pemantauan kualitas air masalah spesifik yang timbul adalah kompleksitas dari variabel yang terukur. Jika pemantauan tidak dirancang dengan baik, banyak data yang telah dikumpulkan namun tidak semuanya bisa dianalisis secara komprehensif, sehingga kurang memberikan informasi yang berguna tentang kondisi perairan. Oleh sebab itu, langkah analisis berupa klasifikasi, pemodelan, dan interpretasi pemantauan data kualitas air merupakan tahapan penting dalam penilaian kualitas air (Boyacioglu, 2006).

Statistik multivariat telah banyak diaplikasikan untuk mengklasifikasikan ataupun menginterpretasi data kualitas perairan. Pendekatan statistik multivariat dari kumpulan data yang tersedia memungkinkan untuk memperoleh informasi yang tersembunyi mengenai kemungkinan pengaruh lingkungan terhadap kualitas perairan. Jenis aplikasi statistik multivariat yang umum digunakan meliputi analisis klaster (cluster analysis), analisis komponen utama (principal component analysis), dan analisis faktor (factor analy- 
sis). Beberapa aplikasi yang telah dilakukan meliputi berbagai ekosistem yang berbeda yaitu danau (Iscen et al., 2008; Kazi et al., 2009), daerah aliran sungai (Simeonov et al., 2003; Singh et al., 2004; Shrestha \& Kazama, 2007), dan perairan pesisir (Kim et al., 2005; Erlania \& Radiarta, 2011). Umumnya aplikasi yang digunakan hanya berdasarkan pendekatan statistik semata, masih jarang yang mengombinasikan dengan analisis spasial menggunakan sistem informasi geografis (SIG).

Tujuan dari penelitian ini adalah untuk menganalisis kondisi kualitas perairan di Kabupaten Morowali dengan pendekatan statistik multivariat dan analisis spasial. Dua teknik statistik multivariat yang diaplikasikan dalam penelitian ini adalah analisis klaster dan analisis komponen utama. Analisis spasial dalam penelitian ini dilakukan dengan menggunakan aplikasi SIG.

\section{BAHAN DAN METODE}

Penelitian ini telah dilaksanakan di perairan Kecamatan Bungku Selatan Kabupaten Morowali Provinsi Sulawesi Tengah (Gambar $1)$. Lokasi penelitian terbentang $122^{\circ} 18^{\prime}$ -

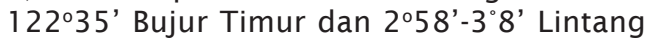
Selatan. Kecamatan Bungku Selatan merupa- kan kecamatan pesisir dan kepulauan dengan jumlah desa pantai mencapai 32 desa dan 22 pulau (Anonim, 2011). Dengan karakteristik lokasi yang terdiri atas pulau-pulau kecil yang cukup terlindung dan perairan karang yang dangkal, menjadikan perairan ini sangat potensial untuk pengembangan budidaya laut. Kecamatan ini telah ditetapkan oleh pemerintah daerah setempat sebagai sentra kawasan minapolitan untuk pengembangan budidaya rumput laut (Kappaphycus alvarezii) dengan metode apung (rawai). Seperti halnya wilayah tropis lainnya, lokasi penelitian dipengaruhi oleh dua musim yaitu musim kemarau (bulan Juni-Oktober) dan musim hujan (bulan Desember-Mei). Kabupaten Morowali tergolong iklim yang sangat basah dengan suhu rata-rata bulanan berkisar antara $26,5^{\circ} \mathrm{C}$ $27,4^{\circ} \mathrm{C}$ (Anonim, 2011).

Pengumpulan data lapangan dilakukan pada bulan Juni 2011 . Titik pengamatan dirancang secara acak sehingga dapat mewakili lokasi perairan yang disurvai. Sebanyak 26 titik pengamatan berhasil dikumpulkan yang mewakili perairan dangkal disekitar pesisir pantai (kawasan budidaya rumput laut) dan perairan dalam (Gambar 1). Pengukuran kualitas air dan pengambilan

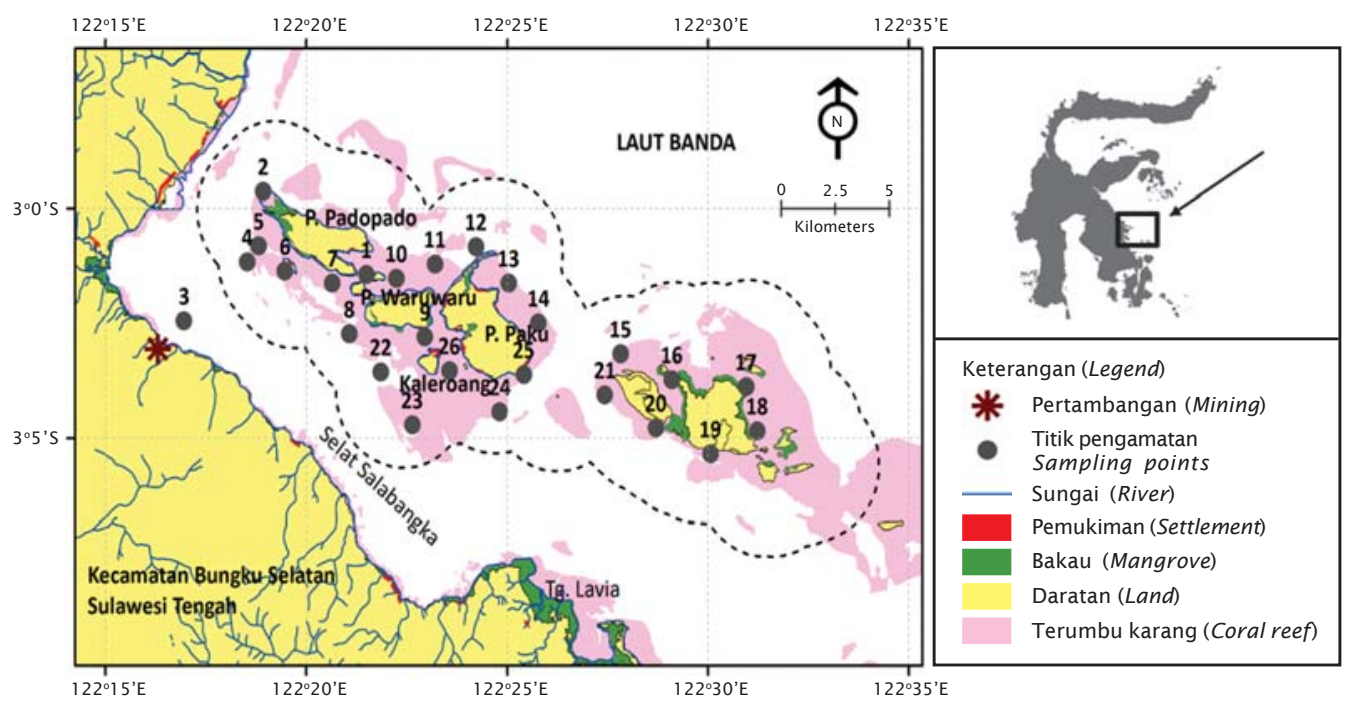

Gambar 1. Lokasi penelitian di Kabupaten Morowali Provinsi Sulawesi Tengah dan sebaran titik pengamatan kualitas perairan (area dengan garis putus-putus digunakan untuk analisis spasial)

Figure 1. The study area in Morowali District Central Sulawesi Province and distribution sampling stations of water quality (polygon with dash line indicates the area for spatial analyses) 
contoh air dilakukan pada kisaran waktu pukul 9.00-13.00, dan pada kedalaman $<1 \mathrm{~m}$. Data yang dikumpulkan dalam penelitian ini meliputi: suhu, salinitas, oksigen terlarut, $\mathrm{pH}$, kekeruhan, nitrit, nitrat, amonia, dan fosfat. Pengukuran suhu, salinitas, oksigen terlarut, dan $\mathrm{pH}$ dilakukan langsung di lapangan dengan menggunakan YSI 650. Parameter lainnya (kekeruhan, nitrit, nitrat, amonia, dan fosfat) dianalisis di Laboratorium Air Balai Penelitian dan Pengembangan Budidaya Air Payau, Maros. Metode pengambilan, preservasi, dan analisis contoh air mengacu pada metode standar SNI 2004 dan SNI 2005. Posisi geografis dari lokasi pengamatan diperoleh dengan menggunakan global positioning system (GPS).

\section{Analisis Statistik Multivariat}

Statistik multivariat yang digunakan untuk menganalisis kondisi kualitas perairan di lokasi penelitian meliputi: analisis klaster (cluster analysis) dan analisis komponen utama (principle component analysis). Seluruh analisis statistik ini menggunakan Microsoft Office Excel 2010 dan SPSS 16.0.

Cluster analysis (CA) adalah analisis multivariat yang umumnya digunakan untuk mengelompokkan objek berdasarkan jarak atau kesamaan karakteristik objek yang akan dikelompokkan. CA mengklasifikasikan objek sehingga objek yang serupa akan dikelompokkan dalam klaster yang sama sesuai dengan kriteria yang digunakan (Iscen et al., 2008; Kazi et al., 2009). Metode CA yang digunakan dalam penelitian ini adalah Hierarchical agglomerative clustering dengan metode Ward (Ward's method) dan squared Euclidean distances untuk mengukur tingkat kesamaan objek. Hasil CA dapat digambarkan dalam bentuk dendogram (diagram pohon).

Principal component analysis (PCA) adalah satu teknik statistik multivariat yang secara linear mengubah bentuk sekumpulan variabel asli menjadi kumpulan yang lebih kecil dan tidak berkorelasi yang dapat mewakili kumpulan variabel aslinya (Iscen et al., 2008; Shrestha \& Kazama, 2007). PCA akan menghasilkan nilai eigen (eigenvalues) dan eigenvectors dari matriks covarian variabel asli. Komponen utama yang terkecil umumnya dipilih (misalnya komponen 1, 2, atau 3), karena mengandung banyak informasi yang dapat menjelaskan keragaman dari variabel asli (Boyacioglu, 2006).

\section{Analisis Spasial}

Analisis spasial digunakan untuk memetakan data kualitas perairan hasil pengukuran dan analisis laboratorium serta hasil analisis PCA. Analisis ini dilakukan dengan teknik interpolasi inverse distance weighted (IDW; Johnson \& McChow, 2001). Seluruh analisis spasial ini menggunakan program ArcGIS v. 10.

\section{HASIL DAN BAHASAN}

\section{Kondisi Kualitas Perairan}

Kualitas perairan merupakan faktor penting yang perlu diperhatikan dalam rangka pemanfaatan lahan baik untuk kegiatan perikanan, pariwisata, pembangkit listrik, sumber air minum, ataupun aktivitas lainnya. Pemantauan kondisi kualitas perairan merupakan tahapan penting dalam pengelolaan dan pemanfaatan lahan guna mendukung keberlanjutan usaha yang dilakukan (GESAMP, 2001). Di lokasi penelitian, lahan pesisir yang tersedia telah dimanfaatkan secara maksimal sebagai lokasi pengembangan budidaya rumput laut (Kappaphycus alvarezii) dengan metode apung (rawai). Hasil pemantauan dan distribusi spasial kondisi kualitas perairan di lokasi penelitian ditampilkan pada Tabel 1 dan Gambar 2. Untuk mengurangi bias yang terjadi, analisis spasial untuk masing-masing parameter kualitas perairan hanya dipetakan untuk wilayah sejauh $3 \mathrm{~km}$ dari garis pantai pulaupulau di lokasi penelitian.

Parameter fisik kualitas perairan (suhu dan kekeruhan) umumnya masih dalam kondisi yang baik untuk mendukung biota laut (Tabel 1). Suhu air yang terukur di lokasi penelitian berkisar antara $27,56^{\circ} \mathrm{C}-29,08^{\circ} \mathrm{C}$. Kisaran nilai ini masih dalam kisaran alami perairan pantai. Sebaran spasial dari suhu perairan terlihat jelas bahwa suhu yang tinggi umumnya tersebar di bagian Barat dan Selatan (sekitar Selat Salabangka) lokasi penelitian, sedangkan suhu yang rendah tersebar di bagian Utara (Gambar 2a). Tingkat kekeruhan perairan berkisar antara 0,1 7-1,13 NTU. Nilai ini masih di bawah baku mutu yang ditetapkan dalam KEPMENLH Nomor 51 tahun 2004 tentang nilai baku mutu air laut untuk biota laut (KLH, 2004). Tingkat kekeruhan perairan yang tinggi ditemukan di bagian Barat lokasi penelitian, sekitar perairan Pulau Padopado (Gambar 2b). Hal ini kemungkinan besar disebabkan lokasinya dekat dengan daratan utama (Pulau Sulawesi) dan lokasi penambangan (Gambar 1). 
Tabel 1. Hasil pengukuran kualitas perairan di perairan Kabupaten Morowali Provinsi Sulawesi Tengah

Table 1. Range of water quality measurement in Morowali District Central Sulawesi Province

\begin{tabular}{|c|c|c|c|c|c|c|c|}
\hline $\begin{array}{l}\text { Parameter } \\
\text { Parameters }\end{array}$ & $\begin{array}{c}\text { Singkatan } \\
\text { Abbrevi- } \\
\text { ation }\end{array}$ & $\begin{array}{l}\text { Sat uan } \\
\text { Unit }\end{array}$ & $\mathbf{N}$ & $\begin{array}{l}\text { Minimum } \\
\text { Minimum }\end{array}$ & $\begin{array}{l}\text { Maksimum } \\
\text { Maximum }\end{array}$ & $\begin{array}{l}\text { Rataan } \\
\text { Mean }\end{array}$ & $\begin{array}{l}\text { Baku mut u } \\
\text { Standard } \\
\text { value }^{*}\end{array}$ \\
\hline $\begin{array}{l}\text { Suhu } \\
\text { Temperature }\end{array}$ & & ${ }^{\circ} \mathrm{C}$ & 26 & 27.56 & 29.08 & 28.29 & $\begin{array}{l}\text { Alami } \\
\text { Natural }\end{array}$ \\
\hline $\begin{array}{l}\text { Kekeruhan } \\
\text { Turbidity }\end{array}$ & & NTU & 26 & 0.17 & 1.13 & 0.44 & $<5$ \\
\hline $\begin{array}{l}\text { Salinitas } \\
\text { Salinity }\end{array}$ & & ppt & 26 & 31 & 32.48 & 31.86 & $\begin{array}{l}\text { Alami } \\
\text { Natural }\end{array}$ \\
\hline $\begin{array}{l}\text { Oksigen te rlarut } \\
\text { Disolved oxygen }\end{array}$ & DO & $\mathrm{mg} / \mathrm{L}$ & 26 & 5.36 & 7.5 & 6.32 & $>5$ \\
\hline $\mathrm{pH}$ & & & 26 & 7.26 & 7.82 & 7.72 & $7-8.5$ \\
\hline Nitrat (Nitrate) & $\mathrm{NO}_{3}$ & $\mathrm{mg} / \mathrm{L}$ & 26 & 0.0015 & 0.1147 & 0.034 & 0.008 \\
\hline Nitrit (Nitrite) & $\mathrm{NO}_{2}$ & $\mathrm{mg} / \mathrm{L}$ & 26 & 0.0016 & 0.0195 & 0.009 & - \\
\hline Amonia (Ammonia) & $\mathrm{NH}_{3}$ & $\mathrm{mg} / \mathrm{L}$ & 26 & 0.0468 & 0.1791 & 0.105 & 0.3 \\
\hline Fosfat (Phosphate) & $\mathrm{PO}_{4}$ & $\mathrm{mg} / \mathrm{L}$ & 26 & 0.0019 & 0.0151 & 0.003 & 0.015 \\
\hline
\end{tabular}

Baku mutu berdasarkan KEPMENLH No. 51 tahun 2004 (Standard value based on KEPMENLH No. 51 year 2004)

Parameter kimia perairan yang diamati meliputi salinitas, oksigen terlarut, $\mathrm{pH}$, nitrat, nitrit, amonia, dan fosfat seluruhnya menunjukkan nilai yang masih sesuai dengan baku mutu, kecuali nitrat (Tabel 1). Salinitas terukur berkisar antara 31,00-32,48 ppt. Salinitas rendah terpantau di ujung Pulau Padopado (Gambar 2c). Pola sebaran ini menunjukkan berbanding terbalik dengan suhu (Gambar 2a) dan kekeruhan (Gambar 2b). Hasil pengukuran oksigen terlarut menunjukkan nilai $>5 \mathrm{mg} / \mathrm{L}$. Sebaran spasial nilai oksigen terlarut yang terukur umumnya menyebar merata di lokasi penelitian, dengan nilai tertinggi terpantau di pulau terluar yang menghadap Laut Banda (Gambar 2d). pH perairan terpantau berkisar antara $7,26-7,82$. Nilai pH yang tinggi umumnya tersebar merata di bagian Selatan lokasi penelitian (Gambar 2e). Tingkat kesuburan perairan yang ditunjukkan melalui parameter nitrat, nitrit, amonia, dan fosfat menunjukkan pola sebaran yang sangat bervariasi (Gambar 2f-i). Hasil pengukuran nitrat menunjukkan kisaran nilai 0,0015-0,1147 mg/L. Sebaran spasial parameter ini menggambarkan beberapa lokasi memiliki nilai yang melebihi baku mutu (> 0,008 mg/L). Lokasi ini berada di sekitar
Pulau Waruwaru dan bagian ujung Timur Pulau Paku (Gambar 2f). Nilai fosfat hasil analisis menunjukkan kisaran 0,0019-0,0151 mg/L; dengan rata-rata $0,003 \mathrm{mg} / \mathrm{L}$. Sebaran spasial parameter fosfat menunjukkan sebagian besar perairan memiliki nilai fosfat yang rendah, hanya dua lokasi yang menunjukkan konsentrasi fosfat yang cukup tinggi yaitu di pesisir pantai Pulau Paku dan Pulau Waruwaru yang menghadap ke Laut Banda (Gambar 2i).

Hasil pemantauan dan pemetaan kondisi kualitas perairan di lokasi penelitian secara umum sangat mendukung untuk kegiatan budidaya laut, baik itu untuk budidaya ikan laut (Beveridge, 1996) ataupun budidaya rumput laut (Tiensongrusmee, 1990; Mubarak et al., 1990). Budidaya rumput laut yang berkembang di lokasi penelitian lebih terkonsentrasi di perairan dangkal yang menghadap ke Selat Salabangka, dengan kedalaman antara 2-15 m. Metode yang digunakan untuk budidaya rumput laut adalah metode apung (rawai). Kondisi ini tentunya sangat mendukung penetapan Kecamatan Bungku Selatan Kabupaten Morowali sebagai sentra pengembangan budidaya rumput laut melalui program minapolitan. 

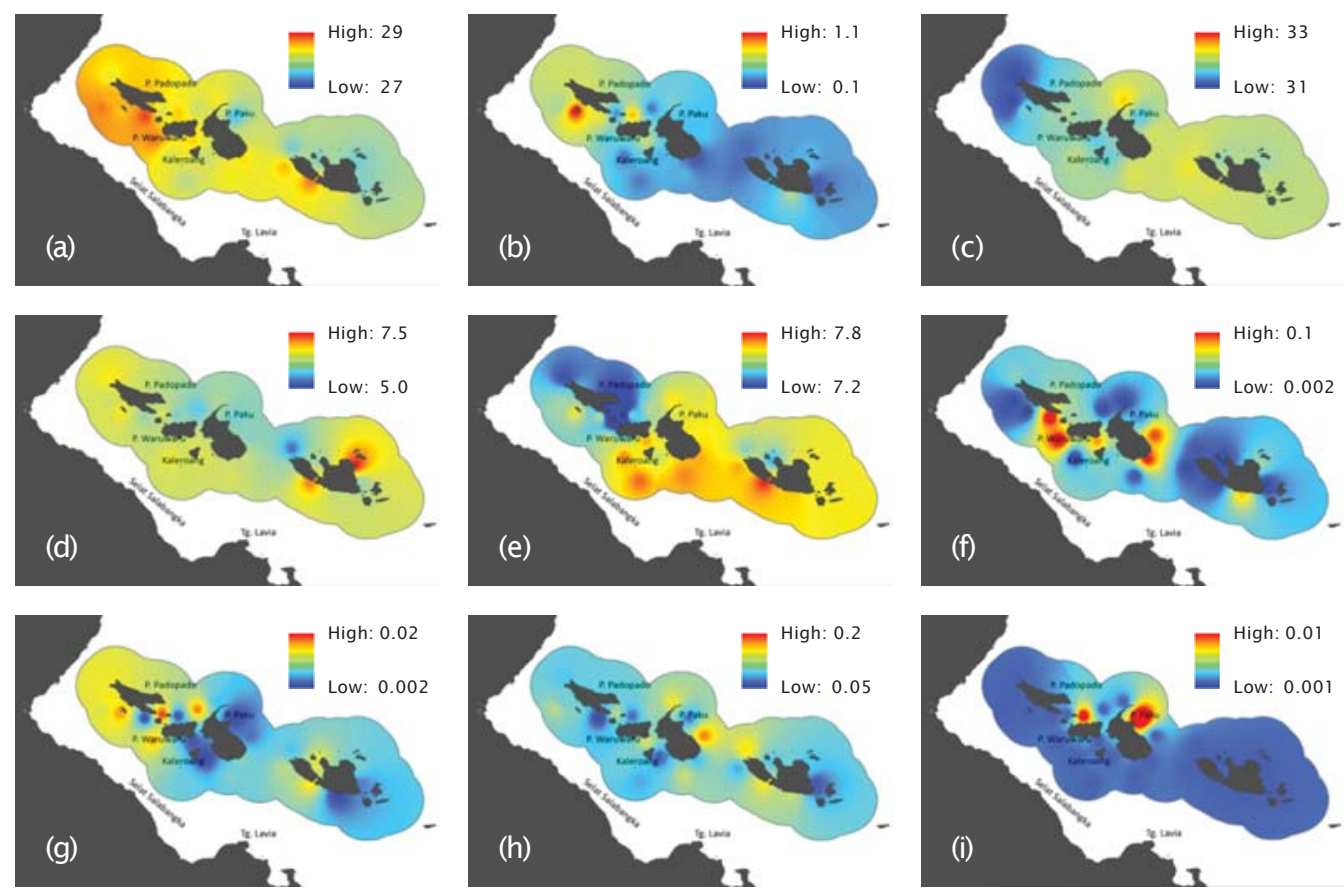

Gambar 2. Peta spasial parameter kualitas perairan di Kabupaten Morowali Provinsi Sulawesi Tengah: (a) suhu air, (b) kekeruhan, (c) salinitas, (d) oksigen terlarut, (e) pH, (f) nitrat, (g) nitrit, (h) amonia, dan (i) fosfat

Figure 2. Spatial maps of water quality parameters in Morowali District Central Sulawesi Province: (a) water temperature, (b) turbidity, (c) salinity, (d) dissolved oxygen, (e) pH, (f) nitrate, $(\mathrm{g})$ nitrite, $(\mathrm{h})$ ammonia, and (i) phosphate

\section{Analisis Klaster}

Analisis klaster (Cluster analysis/CA) digunakan untuk mendeteksi tingkat kesamaan kelompok karakteristik lingkungan perairan di 26 titik pengamatan kualitas perairan. Gambar 3 menunjukkan dendogram hasil CA di lokasi penelitian. Berdasarkan CA, 26 titik pengamatan kualitas air secara signifikan dikelompokkan menjadi dua klaster. Klaster 1 terdiri atas stasiun 2-10. Klaster ini menggambarkan lokasi perairan yang cukup terlindung, berdekatan dengan daratan utama (Pulau Sulawesi), dan dekat lokasi penambangan. Klaster ini dicirikan dengan karakteristik perairan yang hangat, tingkat salinitas yang rendah, dan konsentrasi kekeruhan yang cukup tinggi (Gambar 2). Dampak dari kegiatan penambangan yang telah berlangsung selama ini, sangat mempengaruhi kondisi kualitas perairan. Saat musim hujan tingkat kekeruhan perairan di wilayah ini sangat tinggi, sehingga sangat mempengaruhi aktivitas budidaya rumput laut yang telah berkembang pesat di kawasan ini.

Klaster 2 terdiri atas stasiun pengamatan 1 dan 11-26. Wilayah klaster ini umumnya menjorok keluar menuju perairan laut lepas (Laut Banda). Karakteristik perairan di wilayah klaster ini umumnya memiliki suhu yang lebih rendah, salinitas lebih tinggi, perairan yang lebih bersih yang ditandai dengan tingkat kekeruhan yang rendah, $\mathrm{pH}$ yang lebih tinggi, dan tingkat kesuburan perairan yang relatif rendah (Gambar 2). Wilayah di klaster 2 ini umumnya lebih terbuka, sehingga dampak dari gelombang laut sangat terasa.

Aplikasi CA dalam pemantauan lingkungan perairan sudah banyak dimanfaatkan untuk perairan pantai, daerah aliran sungai, dan waduk/danau (Simeonov et al., 2003; Singh et al., 2004; Kim et al., 2005; Iscen et al., 2008). Dengan menggunakan CA ini, memberikan gambaran yang baik dalam rangka mendesain lokasi pengamatan secara efisien dan efektif 


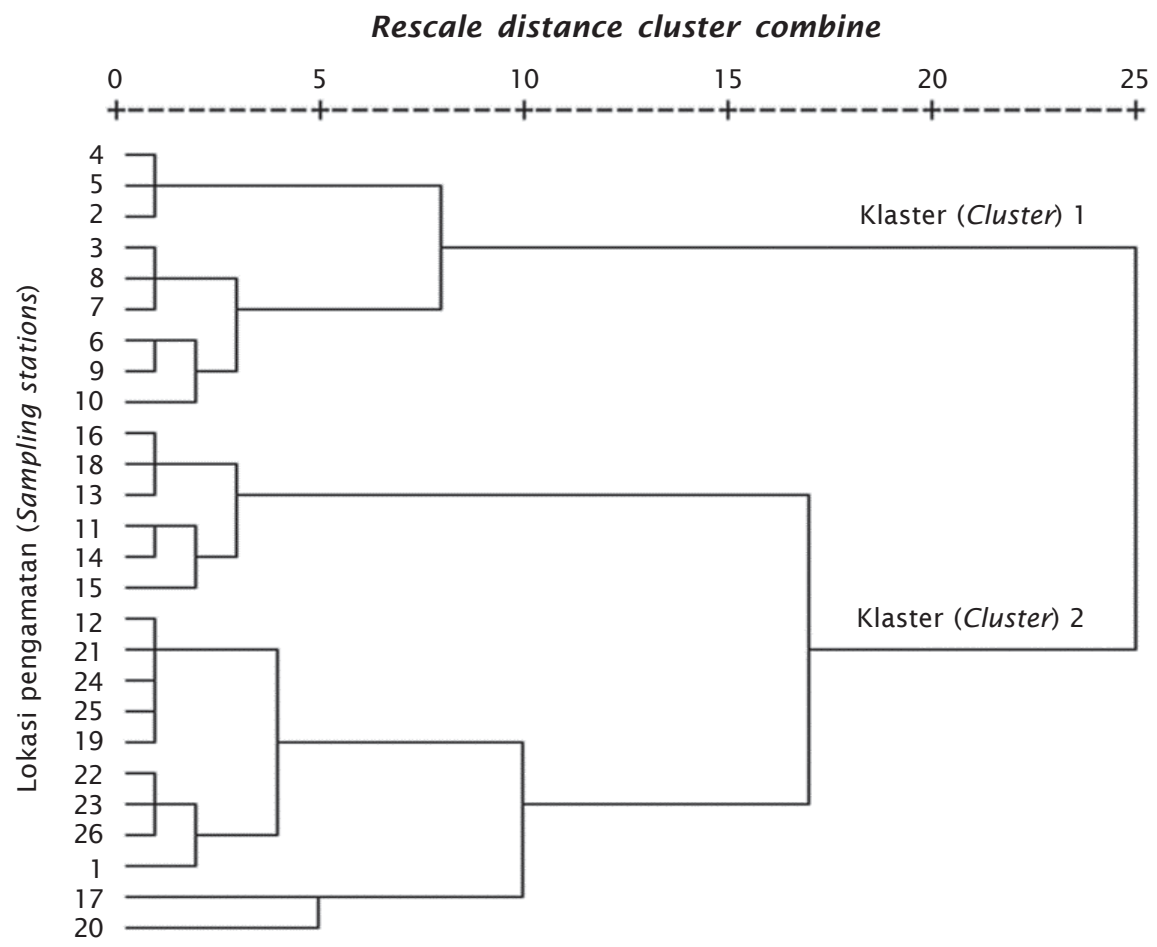

Gambar 3. Dendogram pengelompokan lokasi penelitian berdasarkan kondisi kualitas perairan di Kabupaten Morowali Provinsi Sulawesi Tengah

Figure 3. Dendogram showing clustering of sampling sites according to water quality characteristics in Morowali District Central Sulawesi Province

sesuai dengan karakteristik perairan untuk seluruh lokasi penelitian. Misalnya jumlah stasiun pengamatan bisa ditambah atau dikurangi sesuai dengan klaster yang ada, sehingga dapat menghemat waktu, tenaga, dan biaya.

\section{Analisis Komponen Utama}

PCA adalah statistik multivariat yang dapat digunakan untuk menjelaskan ragam dari sekumpulan data (parameter) yang tidak berkorelasi menjadi beberapa parameter yang dapat berdiri sendiri (komponen utama). Gambar 4 menyajikan seluruh komponen utama (principal component/PC) yang dihasilkan dari PCA. Dari total PC yang dihasilkan tersebut, menunjukkan bahwa hanya empat komponen utama yang berperan penting yaitu PC1-PC4, dengan total persentase kumulatif mencapai 69,180\% dari ragam total (Gambar 4 dan Tabel 2). Pemilihan empat PC ini berdasarkan nilai eigen yang lebih besar dari 1 (Simeonov et al., 2003; Iscen et al., 2008). Jika terdapat nilai eigen yang kurang dari 1 , kom- ponen ini dinyatakan tidak dapat menjelaskan variable dengan baik, sehingga tidak diikutkan dalam pembentukkan variable (Umar, 2009). Dari keempat PC tersebut, PC1 menjelaskan $22,085 \%$ dari ragam total; PC2 memberikan kontribusi sebesar 20,199\%; PC3 menjelaskan 15,376\%; dan PC4 turut menjelaskan sebesar $11,520 \%$ dari ragam total (Tabel 2 ).

Parameter dari kumpulan data untuk empat komponen PCA disajikan pada Tabel 2. Liu et al. (2003) mengelompokkan hasil PCA menjadi tiga kelompok yaitu kuat, sedang dan lemah dengan nilai masing-masing $>0,75 ; 0,75-0,50$; dan 0,50-0,30. PC1 dipengaruhi dengan kategori sedang oleh parameter salinitas dan amonia, sedangkan parameter fosfat memberikan pengaruh negatif terhadap PC1 (Gambar 5). Parameter yang paling berpengaruh di $\mathrm{PC} 1$ adalah salinitas dengan nilai sebesar 0,705.

PC2 menyumbang 20,199\% dari ragam total. Oksigen terlarut merupakan parameter yang memberikan pengaruh kuat terhadap PC2 


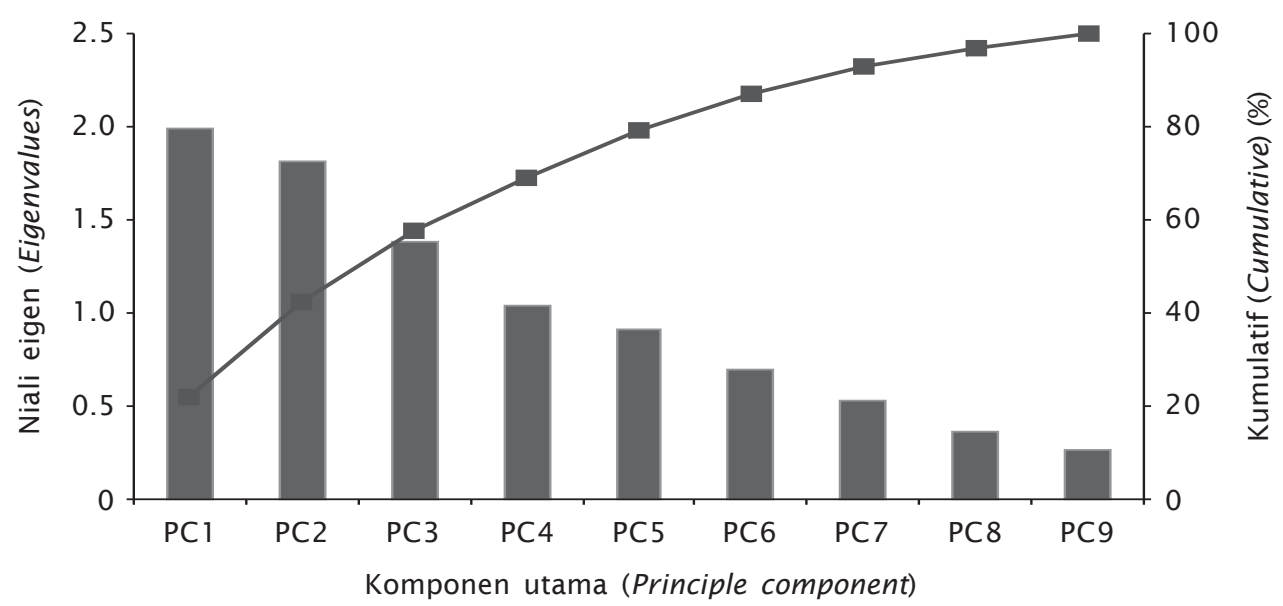

Gambar 4. Nilai eigen dan persentase kumulatif dari analisis komponen utama

Figure 4. Eigenvalues and precentage of cumulative from principal component analysis

Tabel 2. Hasil analisis komponen utama, nilai eigen, variabilitas, dan kumulatif untuk parameter kualitas perairan di Kabupaten Morowali Provinsi Sulawesi Tengah

Table 2. Results of principal component analysis, eigenvalues, variability, and cumulative for water quality parameters in Morowali District Central Sulawesi Province

\begin{tabular}{lcccc}
\hline \multicolumn{1}{c}{$\begin{array}{c}\text { Parameter } \\
\text { Paramet ers }\end{array}$} & \multicolumn{3}{c}{ Komponen utama (Principal component) } \\
\cline { 2 - 5 } & $\mathbf{1}$ & $\mathbf{2}$ & $\mathbf{3}$ & $\mathbf{4}$ \\
\hline Suhu (Water temperature) & - & - & 0.729 & - \\
Salinitas (Salinity) & 0.705 & - & - & - \\
Oksigen terlarut (Dissolve oxygen) & - & 0.793 & - & - \\
pH & - & - & - & 0.888 \\
Nitrat (Nitrate) & - & - & 0.728 & - \\
Nitrit (Nitrite) & - & 0.513 & - & -0.719 \\
Amonia (Ammonia) & 0.679 & - & - & - \\
Fosfat (Phosphat) & -0.628 & -0.533 & - & - \\
Kekeruhan (Turbidity) & - & - & 0.627 & - \\
Nilai eigen (Eigenvalue) & 1.988 & 1.818 & 1.384 & 1.037 \\
Variabilitas (Variability) (\%) & 22.085 & 20.199 & 15.376 & 11.520 \\
Kumulatif (Cumulative) (\%) & 22.085 & 42.284 & 57.660 & 69.180 \\
\hline
\end{tabular}

" Hanya menampilkan nilai > 0,5 (Value above 0.5 have been shown)

(Gambar 5). Nitrit dan fosfat berpengaruh sedang dengan nilai yang relatif sama yaitu 0,513 dan 0,533 . Seperti halnya pada $\mathrm{PC} 1$, di PC2 fosfat juga memberikan pengaruh negatif. PC3 dibentuk dari parameter suhu, nitrat, dan kekeruhan (Gambar 5). Ketiga parameter tersebut berpengaruh sedang terhadap pembentukkan PC3 ini. Untuk PC4, pH merupakan paramater kuat yang membentuknya $(0,888)$. Sedangkan nitrit memberikan pengaruh negatif terhadap PC4 dengan kategori sedang (Tabel 2 dan Gambar 5).

Pemetaan spasial masing-masing PC disajikan pada Gambar 6. PC1 dengan kontribusi sebesar $22,085 \%$; pola penyebarannya me- 


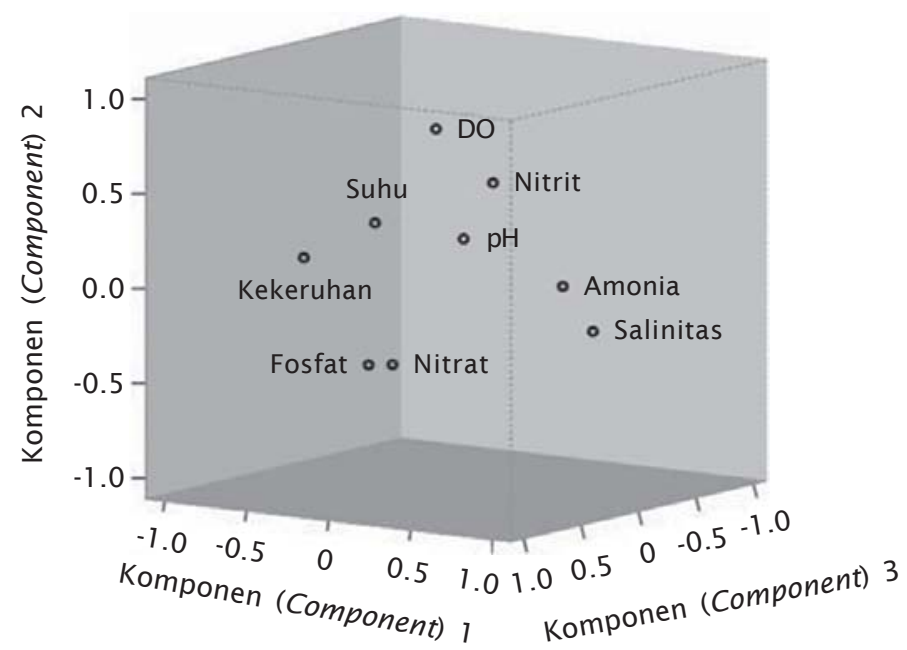

Gambar 5. Plot analisis komponen utama untuk kondisi kualitas perairan di Kabupaten Morowali Provinsi Sulawesi Tengah

Figure 5. Principal component analysis plot for water quality characteristics in Morowali District Central Sulawesi Province

nunjukkan nilai skor yang kecil terkonsentrasi di sekitar Pulau Padopado, sedangkan nilai skor yang relatif tinggi tersebar merata di bagian Tenggara (Gambar 6a). Pola yang serupa ditunjukkan oleh PC4 (Gambar 6d). Untuk sebaran spasial PC2 dan PC3 (Gambar 6b-c) umumnya menunjukkan pola yang berbanding terbalik dengan PC1 dan PC4. Wilayah perairan sekitar Pulau Padopado dicirikan dengan nilai skor PC yang besar, sebaliknya perairan di bagian Tenggara (Pulau Waruwaru, Pulau Paku, Kaleroang, dan pulau-pulau terluar) memiliki nilai skor PC yang relatif rendah (Gambar 6bc). Sebaran spasial yang dihasilkan dari keempat PC ini menggambarkan pola pembagian wilayah perairan yang serupa dengan hasil CA yaitu secara umum membagi wilayah perairan lokasi penelitian menjadi dua wilayah dengan karakteristik perairan yang unik. Tampilan spasial PCA ini sangat membantu menginterpretasikan hasil analisis secara statistik pada suatu kawasan penelitian. Hasil serupa juga telah dilakukan oleh Liu et al. (2003) untuk mengkaji kualitas tanah berhubungan dengan penyebaran penyakit Blackfoot di Taiwan.

\section{KESIMPULAN}

Penelitian ini menyajikan kegunaan dari analisis statistik multivariat yang dipadukan dengan analisis spasial untuk mendapatkan informasi yang lebih baik tentang karakteristik kualitas perairan. Beberapa teknik statistik multivariat telah digunakan dalam penelitian ini untuk mengevaluasi variasi dalam kualitas perairan pesisir di Kabupaten Morowali. Analisis klaster membagi 26 titik pengamatan kualitas air menjadi dua kelompok yang memiliki karakteristik kualitas perairan yang sama yaitu perairan di sekitar Pulau Padopado dan perairan di bagian Tenggara (Pulau Waruwaru, Pulau Paku, Kaleroang, dan pulaupulau terluar). Dengan analisis klaster ini dapat digunakan untuk merancang lokasi titik pengamatan di masa yang akan datang sehingga lebih efektif dan efisien. Penajaman analisis dengan PCA yang memberikan nilai kumulatif sebesar $69,180 \%$ untuk empat PC (PC1-PC4), secara spasial menunjukkan pola sebaran yang serupa dengan hasil analisis klaster. Secara umum kedua analisis statistik yang digunakan dalam penelitian ini membagi lokasi penelitian menjadi dua wilayah yang berbeda yaitu wilayah perairan bagian Barat (Pulau Padopado) dan wilayah bagian Tenggara yang lebih berhadapan dengan laut lepas (Pulau Waruwaru, Pulau Paku, Kaleroang, dan pulau-pulau terluar).

\section{UCAPAN TERIMA KASIH}

Penulis mengucapkan terima kasih kepada Dinas Kelautan dan Perikanan Kabupaten Morowali atas bantuannya selama kegiatan 


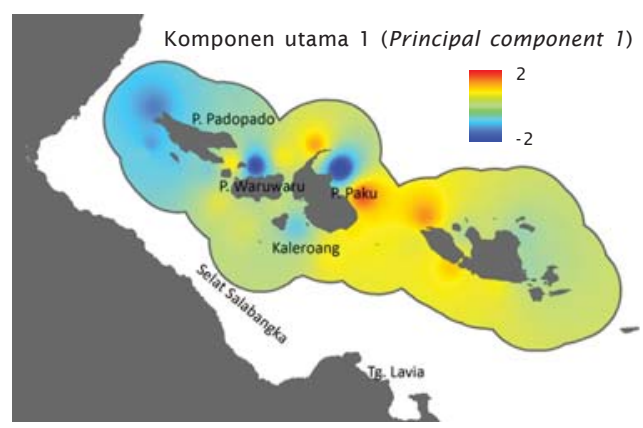

(a) PC 1 - Variabilitas (Variability): 22,085\%

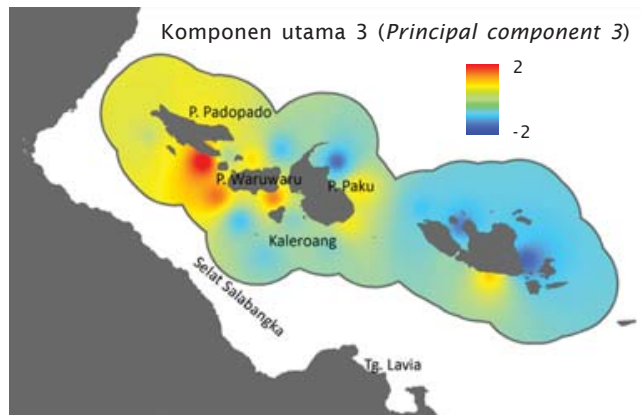

(c) PC 3 - Variabilitas (Variability): 15,376\%

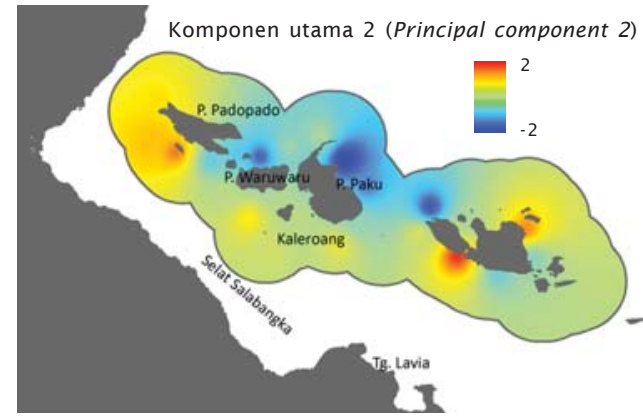

(b) PC 2 - Variabilitas (Variability): 20,199\%

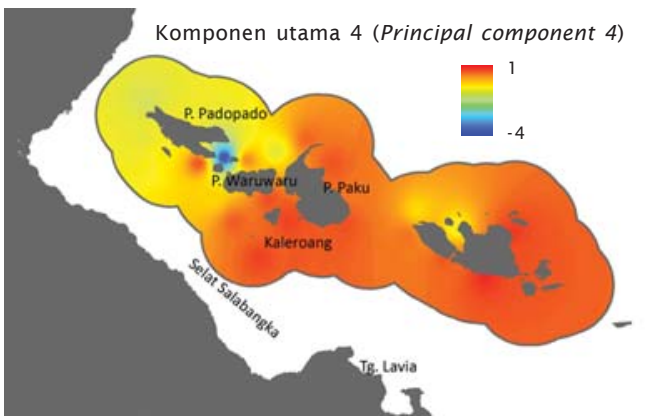

(d) PC 4 - Variabilitas (Variability): 11,520\%

Gambar 6. Pemetaan analisis komponen utama di perairan Kabupaten Morowali Provinsi Sulawesi Tengah: (a) komponen utama 1, (b) komponen utama 2, (c) komponen utama 3, dan (d) komponen utama 4

Figure 6. Spatial maps of principal component analysis in Morowali District Central Sulawesi Province: (a) principle component 1, (b) principle component 2, (c) principle component 3 , and (d) principle component 4

lapangan. Kami juga mengucapkan terima kasih kepada tim survai minapolitan: Sdr. Makmur, Rizky Antoni, Suheemi, dan Mat Fahrur yang telah membantu kelancaran pengumpulan data lapangan. Penelitian ini merupakan bagian dari penelitian Kajian Kelayakan Lahan untuk Minapolitan Pusat Penelitian dan Pengembangan Perikanan Budidaya Tahun Anggaran 2011.

\section{DAFTAR ACUAN}

Anonim. 2011 . Masterplan kawasan minapolitan Kabupaten Morowali. Dinas Kelautan dan Perikanan Kabupaten Morowali, 92 hlm.

Beveridge, M.C.M. 1996. Cage Aquaculture (Eds. $\left.2^{\text {nd }}\right)$. Fishing News Books LTD. Farnham, Surrey, England, 352 pp.

Boyacioglu, H. 2006. Surface water quality assessment using factor analysis. Water S.A., 32(3): 389-393.
Erlania \& Radiarta, I N. 2011 . Kondisi kualitas perairan di Teluk Lada Pandeglang Provinsi Banten untuk mendukung budidaya kerang hijau (Perna viridis). J. Ris. Akuakultur, 6(3): 507-519.

GESAMP (IMO/FAO/Unesco-IOC/WMO/WHO/ IAEA/UN/UNEP Joint Group of Experts on the Scientific Aspects of Marine Environmental Protection). 2001. Planning and management for sustainable coastal aquaculture development. FAO Rep. Stud. GESAMP No. 68.90 pp.

Iscen, C.F., Emiroglu, O., Ilhan, S., Arslan, N., Yilmaz, V., \& Ahiska, S. 2008. Application of multivariate statistical techniques in the assessment of surface water quality in Uluabat Lake, Turkey. Environmental Monitoring Assessment, 144: 269-276.

Johnson, K. \& McChow, J. 2001. Using ArcGIS spatial analysis. Environmental Systems 
Research Institute (ESRI), Inc., USA, 236 pp.

Kazi, T.G., Arain, M.B., Jamali, M.K., Jalbani, N., Afridi, H.I., Sarfraz, R.A., Baig, J.A., \& Shah, A.Q. 2009. Assessment of water quality polluted lake using multivariate statistical technique: a case study. Ecotoxixology and Environmental Safety, 72: 301-309.

Kim, J.H., Kim, R.H., Lee, J., Cheong, T.J., Yum, B.W., \& Chang, H.W. 2005. Multivariate statistical analysis to identify the major factors governing roundwater quality in the coastal area of Kimje, South Korea. Hydrol. Process., 19: 1,261-1,276.

Kementerian Lingkungan Hidup (KLH). 2004. Keputusan Menteri Negara Kependudukan dan Lingkungan Hidup No. 51 tahun 2004, tanggal 8 April 2004 tentang baku mutu air laut. Kementerian Lingkungan Hidup. Jakarta, $11 \mathrm{hlm}$.

Liu, C.W., Lin, K.H., \& Kuo, Y.M. 2003. Application of factor analysis in the assessment of groundwater quality in a Blackfoot disease area in Taiwan. Science of the Total Environment, 313: 77-89.

Mubarak, H., Ilyas, S., Ismail, W., Wahyuni, I.S., Hartati, S.H., Pratiwi, E., Jangkaru, Z., \& Arifudin, R. 1990. Petunjuk teknis budidaya rumput laut. Badan Litbang Pertanian,
Puslitbang Perikanan. IDRC, Infish, $93 \mathrm{hlm}$. Singh, K.P., Malik, A., Mohan, D., \& Sinha, S. 2004. Multivariate statistical techniques for the evaluation of spatial and temporal variations in water quality of Gomti river (India): a case study. Water Res., 38: 3,980-3,992.

Simeonov, V., Stratis, J.A., Samara, C., Zachariadis, G., Voutsa, D., Anthemidis, A., Sofonious, M., \& Kouimtzis, T. 2003. Assessment of the surface water quality in Northern Greece. Water Research, 37: 4,1194,124 .

Shrestha, S. \& Kazama, F. 2007. Assessment of surface water quality using multivariate statistical techniques: A case study of the Fuji river basin; Japan. Environmental Modelling \& Software, 22: 464-475.

Tiensongrusmee, B. 1990. Site selection for Eucheuma spp. farming. UNDP/FAO Regional Seafarming Development and Demonstration Project (RAS/90/002). Kasetsart University Campus, Bangkok, Thailand. http://www.fao.org/docrep/field/003/ AB738E/AB738E00.htm\#TOC disadur tanggal 30 November 2010.

Umar, H.B. 2009. Principle component analysis (PCA) dan aplikasi dengan SPSS. J. Kesehatan Masyarakat, 3(2): 97-101. 